\begin{tabular}{|l|l|l||}
\hline \multicolumn{2}{|c|}{ PublisherInfo } \\
\hline \hline PublisherName & $:$ & BioMed Central \\
\hline \hline PublisherLocation & $:$ & London \\
\hline \hline PublisherImprintName & $:$ & BioMed Central \\
\hline \hline
\end{tabular}

\title{
ER and control of cyclin D1 expression
}

\begin{tabular}{|l|l|l||}
\hline \multicolumn{2}{|c|}{ ArticleInfo } \\
\hline \hline ArticleID & $:$ & 3646 \\
\hline \hline ArticleDOI & $:$ & $10.1186 /$ bcr-1999-66624 \\
\hline \hline ArticleCitationID & $:$ & 66624 \\
\hline \hline ArticleSequenceNumber & $:$ & 66 \\
\hline \hline ArticleCategory & $:$ & Paper Report \\
\hline ArticleFirstPage & $:$ & 1 \\
\hline \hline ArticleLastPage & $:$ & 3 \\
\hline \hline & & RegistrationDate : 1999-12-2 \\
\hline ArticleHistory & $:$ & OnlineDate \\
\hline \hline ArticleCopyright & $:$ & Current Science Ltd1999-12-2 \\
\hline \hline ArticleGrants & $:$ & \\
\hline \hline ArticleContext & $:$ & 1305811 \\
\hline \hline
\end{tabular}




\section{Keywords}

AP-1, cyclin D1, oestrogen receptor, proliferation

\section{Introduction}

Oestrogen receptor (ER) function can induce cyclin D1 expression leading to proliferation in human breast cancer cells (MCF-7). Recent studies showing that ER-positive epithelial cells in the human mammary gland are nonproliferative indicate that a direct mitogenic effect of oestrogen on mammary epithelial cells is gained during breast tumorigenesis.

\section{Aims}

To determine whether stable transfection of the ER into normal or tumour cell lines that are ER negative can confer oestrogen responsiveness in terms of cell proliferation induced via the cyclin D1 pathway.

\section{Comments}

This paper describes a molecular analysis of oestrogen control of proliferation in ER-transfected cells and ER-positive breast cancer cells. The reported differences may account for the observed separation between ER expression and cell division in normal but not malignant breast epithelium. The results indicate an important regulatory alteration in breast cells during neoplastic transformation.

\section{Methods}

MDA-MB-231 breast cancer cells and $\mathrm{HaCaT}$ nontransformed human keratinocytes were stably transfected with a vector expressing ER. Western blot analysis of cell extracts following oestrogen treatment was carried out for ER, cyclin D1, c-Fos and c-Jun. 


\section{Results}

In contrast to the ER-positive MCF-7 breast cancer cell line, ER-negative breast cancer cells (MDAMB-231) and nontransformed human keratinocytes $(\mathrm{HaCaT})$ stably expressing the ER are unable to proliferate or to regulate cyclin D1 expression in response to oestrogen. Although oestrogen stimulation of MCF-7 cells induces the AP-1 family components c-Fos and c-Jun, this does not occur in HaCaT cells expressing the ER, which may explain the inability to positively regulate cyclin D1 and proliferation.

\section{Discussion}

While ER-transfected ER-negative cells have been reported to drive a reporter gene linked to the oestrogen response element, stimulation of proliferation does not occur. This contrasts with ER-positive MCF-7 breast cancer cells where control of proliferation by oestrogen appears to be via the cell cycle gene cyclin D1. Thus, ER function alone does not suffice for oestrogen-dependent cyclin D1 expression and proliferation. Other transcriptional cofactors that allow the ER to regulate expression of AP-1 and cyclin D1 may be necessary for oestrogen to act as a mitogen, and may represent a pathological change acquired during breast cancer tumorigenesis.

\section{References}

1. Planas-Silva MD, Donaher JL, Weinberg RA: Functional activity of ectopically expressed estrogen receptor is not sufficient for estrogen-mediated cyclin D1 expression. Cancer Res. 1999, 59: 4788-4792. 